Full length article

\title{
Socially responsible investors and the disposition effect
}

\author{
Bono van Dooren, Rients Galema* \\ Utrecht University, School of Economics, P.O. Box 80125, 3508 TC Utrecht, Netherlands
}

\section{A R T I C L E I N F O}

\section{Article history:}

Received 16 October 2017

Accepted 19 December 2017

Available online 27 December 2017

\section{Keywords:}

Disposition effect

Socially responsible investment

\begin{abstract}
A B S T R A C T
In this paper we analyze the possible interaction between socially responsible investment and the disposition effect-the tendency to hold losing stocks too long and sell winning stocks too early. We analyze trading and portfolio data from a large retail bank and find that socially responsible investors display a greater disposition effect than conventional investors. Only when investors invest a substantial proportion of their portfolio in socially responsible stocks do we find evidence for a differential disposition effect, whereas we do not find evidence for a relationship between the percentage invested in socially responsible stocks and the disposition effect.
\end{abstract}

(C) 2017 Published by Elsevier B.V.

\section{Introduction}

The disposition effect is the tendency to sell appreciated stocks (winners) too early and hold depreciated stocks (losers) too long (Shefrin and Statman, 1985; Odean, 1998). This behavioral bias has been found at the aggregate market level (Ferris et al., 1988; Heath et al., 1999) and at the individual level (Dhar and Zhu, 2006; Barber et al., 2007; Barber and Odean, 2000). A large body of research tries to explain what drives the disposition effect, with explanations based on wealth maximizing strategies (Brown et al., 2006), Kahnemann's (Kahneman and Tversky, 1979) prospect theory (Barberis and Xiong, 2009) and mean reversion (Weber and Camerer, 1998; Odean, 1998). Not all investors seem to be equally affected by the disposition effect. It appears to be correlated with individual characteristics like sophistication (Dhar and Zhu, 2006) ethical background (Frino et al., 2015), and confidence and self-regard (Kadous et al., 2014), amongst others. This paper investigates whether the extent to which investors invest socially responsibly affects the disposition effect.

Socially responsible investment (SRI) is an investment strategy that considers attributes other than risk and return to select investments. Research suggests that in addition to risk-return considerations social preferences are likely to explain why investors invest responsibly (Riedl and Smeets, forthcoming; Bauer and Smeets, 2015; Williams, 2007; Webley et al., 2001). That is, socially responsible investors derive utility from consuming a social responsibility attribute (Heinkel et al., 2001; Mackey et al., 2007; Dam and Scholtens, 2015). When investors rationally deviate from optimizing their utility solely based on risk and return, equilibrium outcomes will deviate from CAPM (Fama and French, 2007), even

\footnotetext{
* Corresponding author.

E-mail address: r.j.galema@uu.nl (R. Galema).
}

without considering behavioral biases. In this paper we hypothesize that social preferences for investments make investors hold on to losing stocks longer and sell winning stocks earlier. That is, we expect socially responsible investors will display a greater disposition effect than conventional investors.

We use unique proprietary brokerage data from a large multinational retail bank that combines customers' portfolio holdings and transactions with stocks' social responsibility information provided by the bank to its customers. Controlling for individual and portfolio-level characteristics that show results largely in line with existing literature (e.g. Dhar and Zhu, 2006; Feng and Seasholes, 2005), we find that socially responsible investors exhibit a greater disposition effect than conventional investors. We do not find evidence of a significant relationship between the percentage of the portfolio allocated to socially responsible investments and the disposition effect. Instead, we only find evidence for a differential disposition effect when socially responsible investors allocate a substantial fraction of their portfolio to socially responsible stocks. Our results hold under various robustness tests.

This paper makes two contributions. First, we add to the disposition effect literature that has recently started to focus on the psychological and social dimension of investors' trading behavior (Kadous et al., 2014; Chang et al., 2016; Heimer, 2016; Rau, 2015). Evidence shows that individual investment behavior is influenced by investors' psychological disposition and social environment. Specifically, the disposition effect has been related to factors like confidence, self-regard, cognitive dissonance and social interaction between peer-investors (Kadous et al., 2014; Chang et al., 2016; Heimer, 2016; Rau, 2015). Our contribution is to investigate to what extent the tendency to invest socially responsible - possibly motivated by social preferences for certain investments - is related to the disposition effect. 
Second, we add to the literature on socially responsible investment by showing that in addition to changing investment behavior (Riedl and Smeets, forthcoming; Heinkel et al., 2001; Mackey et al., 2007; Dam and Scholtens, 2015), investing socially responsibly also biases individual trading patterns. Within the SRI literature our paper is related to Benson and Humphrey (2008) who find that SRI fund flows are less sensitive to past returns than conventional fund flows and Bollen (2007), who finds evidence of an asymmetric response of cash flows into socially responsible mutual funds, which are more sensitive to lagged positive returns and less sensitive to lagged negative returns. Instead of analyzing socially responsible mutual fund flows, we use brokerage data on individual investors' portfolios to analyze stock investments instead of mutual fund flows. ${ }^{1}$ So we directly measure the disposition effect of individual investors for which Chang et al. (2016) show the disposition effect holds mostly.

\section{Literature and hypotheses}

\subsection{Socially responsible investment}

The socially responsible investment (SRI) industry has been growing rapidly over the last decades, increasingly generating academic interest (Renneboog et al., 2008). One of the questions is: "What motivates investors to hold socially responsible stocks?" Investors could be attracted to socially responsible stocks when they expect risk-adjusted returns on these stocks to be higher, but studies in the SRI performance literature offer equivocal results. Some studies suggest that socially responsible investment returns are better or at least not significantly different from conventional investment returns (Derwall et al., 2005; Kempf and Osthoff, 2007; Edmans, 2011; Bauer et al., 2005), whereas other studies find evidence of significant SRI underperformance (Hong and Kacperczyk, 2009; Fabozzi et al., 2008).

According to another explanation, socially responsible investors derive utility from owning stocks of companies that are consistent with a set of personal values or societal concerns. Several papers investigate the social motivations behind SRI. Williams (2007) uses data from a large survey of investors across five countries and shows that SRI is likely more driven by investors' appreciation of firms' social aims than firms' financial returns. Riedl and Smeets (forthcoming) show that investors hold SRI mutual funds mainly because of their intrinsic social preferences, whereas financial motivations play a much smaller role. In addition, they show investors are willing to accept lower financial returns on SRI. Bauer and Smeets (2015) show that investors that identify themselves more strongly with SRI allocate substantially more wealth to socially responsible investments. Webley et al. (2001) provides experimental evidence that confirms social factors motivate investments. In sum, the literature provides support for the assertion that socially responsible investors derive additional utility from investing responsibly.

\subsection{Disposition effect and socially responsible investment}

The list of possible explanations for the disposition effect is extensive (See Kaustia, 2011 for an overview) and provides several reasons for why the disposition effect could be greater for socially responsible investors. Early studies of the disposition effect include wealth-maximizing strategies like portfolio rebalancing, tax avoidance and transaction cost minimization (Shefrin and Statman, 1985; Odean, 1998; Ferris et al., 1988). The disposition effect could

\footnotetext{
1 This is common practice in the disposition effect literature (Dhar and Zhu, 2006; Odean, 1998; Frino et al., 2015), but the socially responsible investment literature either analyzes mutual fund data (e.g. Renneboog et al., 2008; Riedl and Smeets, forthcoming; El Ghoul and Karoui, 2017), or constructs portfolios from social responsibility ratings to analyze performance (e.g. Kempf and Osthoff, 2007; Galema et al., 2008).
}

impose substantial costs on investors to the extent the impairment of rational forward-looking decision-making reduces investment performance and has investors pay more capital gain taxes than necessary (Kaustia, 2011). Because socially responsible investors could be less motivated by financial returns (Williams, 2007; Riedl and Smeets, forthcoming; Webley et al., 2001), they might care less about these costs than conventional investors.

A key explanation for the disposition effect features prospect theory (Kahneman and Tversky, 1979), which explains investors' asymmetric response to performance. According to prospect theory, investors maximize their utility given an S-shaped value function defined on gains and losses. Applying prospect theory to investing, the purchase price of a stock is seen as the reference point, vis-à-vis which gains and losses are evaluated. Price increases imply investors are in the domain of gains where they are riskaverse and therefore relatively insensitive to further gains, making them more willing to sell early. Price decreases imply investors are in the domain of losses where they are risk-seeking and therefore relatively insensitive to further losses, making them more willing to hold on to a stock. Socially responsible investors could be more willing to hold on to losing stocks if their disutility is compensated with the utility derived from investing responsibly.

An alternative explanation for the disposition effect is the belief of investors in mean reversion (Odean, 1998). Investors may believe stocks experiencing recent wins are likely to fall, and stocks experiencing recent losses are likely to rebound. Investors could believe socially responsible stocks are more robust and therefore more likely than conventional stocks to feature mean reversion. Bollen (2007) proposes both prospect theory and expected mean reversion of mutual fund performance as possible explanations for the asymmetric result that cash flows into socially responsible mutual funds are more sensitive to past positive returns and less sensitive to past negative returns than those observed at conventional mutual funds.

More recent contributions on the disposition effect focus on individual investors and investor psychology. Dhar and Zhu (2006) confirm the overall disposition effect, and investigate the variation of the disposition effect across individuals. Kadous et al. (2014) show the disposition effect is positively related to confidence and negatively to self-regard. Chang et al. (2016) show the disposition effect is related to cognitive dissonance, which is the discomfort that arises when recognizing ones' choices and/or beliefs are inconsistent with each other. Cognitive dissonance arises from the tension between the original investment decision that is based on the trader being convinced of having bought the asset for a good reason and the subsequent decrease in value that suggests otherwise. Traders can deal with this dissonance by holding on to the losing stock, rationalizing the recent poor performance as a temporary setback or introducing an ameliorating condition like blaming a delegated manager (Chang et al., 2016). ${ }^{2}$ Socially responsible investors could preserve self-image by holding on to a losing stock and convincing themselves that they still invested in a "good", socially responsible stock, despite its recent negative financial performance.

Also social interactions matter for the disposition effect. Rau (2015) finds that investors that trade in teams display a more pronounced disposition effect than those trading alone. Investors may be reluctant to admit to their peer group that they made a wrong call on an investment: Heimer (2016) shows that traders connected through an online trading platform display correlated levels of the disposition effect and access to the platform nearly doubles traders' disposition effect. Riedl and Smeets (forthcoming)

\footnotetext{
2 Chang et al. (2016) find that delegated fund managers display a reverse disposition effect, which is consistent with blaming the fund manager and thereby preserving self-image.
} 
shows that socially responsible investors are more likely than conventional investors to talk about their investments with others. Specifically, social signaling - talking about ones' investments - is positively related to the likelihood of holding socially responsible mutual funds. In addition, based on cognitive dissonance (Chang et al., 2016), socially responsible investment might also work as an ameliorating condition towards an investor's peer group. That is, it is easier to admit making a wrong call if an investor can claim towards its peer group to hold a losing stock for social reasons.

\subsection{Hypotheses}

Based on the disposition effect literature, on average we would expect to find a disposition effect for our entire sample of investors. $^{3}$ Our investigation centers around finding a differential disposition effect for socially responsible investors as compared to conventional investors. Our null hypothesis is that there is no differential effect. Even if social preferences affect investors' stock holdings, the same social preferences may have little to no effect on trading behavior. Socially responsible investors choose their investments from a smaller, responsible investment universe, but possibly they then just trade like conventional investors do. This would imply that trades based on past gains and losses are not influenced by the utility derived from investing socially responsibly.

The alternative hypothesis is that socially responsible investors display a disposition effect that differs from that of conventional investors. Bollen (2007) makes the assumption that socially responsible investors could be represented by a multi-attribute utility function that is defined over a variable that indicates whether an investment is socially responsible and the moments of the portfolio return distribution. Assuming socially responsible investments are also selected on a financial basis (i.e. investors have a conditional utility function) socially responsible investors derive additional utility from consuming the social responsibility attribute. The positive utility derived from investing socially responsibly implies that investors would be willing to accept a lower financial gain before selling because they derive additional utility from consuming the social responsibility attribute. In the area of losses, the positive utility derived from investing socially responsibly implies investors would be willing to hold on to losing stocks longer. Combined with an asymmetric response to past performance, this would predict that socially responsible investors display a greater disposition effect.

In addition to utility-based explanations and as discussed in the literature review, socially responsible investors could also be more likely to display the disposition effect if they are more likely to expect stocks returns to feature mean reversion (Odean, 1998), if they are more prone to cognitive dissonance and other psychological biases associated with trading less rationally (Dhar and Zhu, 2006; Kadous et al., 2014; Chang et al., 2016) and if they are more sensitive to their peers and social environment (Heimer, 2016; Riedl and Smeets, forthcoming; Rau, 2015) than conventional investors. Therefore, we hypothesize:

Hypothesis 1. Socially responsible investors display a greater disposition effect than conventional investors.

Riedl and Smeets (forthcoming) find that social preferences matter only in deciding whether to invest in a socially responsible mutual fund; conditional on investing they do not matter for the amount invested. Possibly, only when socially responsible investors identify themselves as such (like in Bauer and Smeets, 2015), they derive utility from the social responsibility attribute.

\footnotetext{
3 In results available on request we indeed find a significant disposition effect for the entire sample.
}

The main argument supporting Hypothesis 1 is that the trading behavior of socially responsible investors is different from conventional investors, which we identify by virtue of them investing only in socially responsible stocks. Alternatively, socially responsible stocks could be different from conventional stocks such that investors trading these stocks are more likely to display the disposition effect. For example, if socially responsible stocks are more subject to mean reversion (Odean, 1998) than conventional stocks, investors holding more of these stocks could be more likely to display the disposition effect. Therefore, we use individual investors' stock holdings to assess to what extent each investor's portfolio contains socially responsible stocks to hypothesize:

Hypothesis 2. Investors display a greater disposition effect when a larger percentage of their portfolio is allocated to socially responsible stocks.

Between the extremes of identifying socially responsible investors as those that invest $100 \%$ in socially responsible stocks and identifying the degree of socially responsible investments as a continuous measure, we explore whether there might be a minimum percentage allocated to socially responsible stocks that is necessary to still observe a difference between the disposition effect of socially responsible and conventional investors. If we would only observe a relationship between the percentage allocated to socially responsible stocks and the disposition effect above a relatively high threshold, this would be in line with Hypothesis 1 and explanations based on investors regarding themselves to be socially responsible investors (Bauer and Smeets, 2015). If we would find evidence of a lower threshold that is relatively low, then this would be more in line with Hypothesis 2 and explanations based on differences between socially responsible and conventional stocks. In that case, we would also expect to find direct evidence for Hypothesis 2 based on a positive relationship between the percentage of the portfolio allocated to socially responsible stocks and the disposition effect.

\section{Data and methodology}

\subsection{Disposition effect}

We follow Dhar and Zhu (2006) in applying the disposition effect measure suggested by Odean (1998) to individual investors. We calculate the disposition effect as the difference between the Proportion of Gains Realized (PGR) and Proportion of Losses Realized (PLR). Each time an investor sells a stock we count the number of Realized Gains (RG), Realized Losses (RL), Paper Gains (PG) and Paper Losses (PL). When an investor sells a stock, the price is compared to the average buying price of this stock for this investor. This average buying price is calculated over the entire transaction history if available and over the sample period otherwise. If there is no buying price available, the stock for this investor will be excluded. If the selling price is higher (lower) than the average buying price, the sale is defined as a realized winner (loser).

For the remaining stocks in the portfolio that are not sold, the average buying price is compared to the high and low price for that day. If the buying price is higher (lower) than both, it is defined as a paper loser (winner). A Realized Gain (Loss) is defined as the number of winner (loser) stocks sold in an investor's portfolio, a Paper Gain (Loss) as the number of winner (loser) stocks in an investor's portfolio. The Proportion of Gains Realized (PGR) and Proportion of Losses Realized (PLR) are defined as:

$$
\begin{aligned}
& P G R=\frac{R G}{R G+P G} \\
& P L R=\frac{R L}{R L+P L}
\end{aligned}
$$


The disposition effect $(D E)$ is defined as the difference between $P G R$ and PLR for each investor for each transaction day:

$D E=P G R-P L R$

Individual investors are more likely to realize gains than to realize losses in their portfolio when they display a positive disposition effect, and this likelihood is increasing in the size of DE.

\subsection{Socially responsible investors}

In our main analyses, socially responsible investors are defined as investors that only hold socially responsible stocks. If investors during the sample period hold one or more stocks that are not socially responsible, they are considered to be conventional investors. ${ }^{4}$ Information on whether a stock is a socially responsible investment is provided by the bank to all investors on its trading platform.

We identify which stocks are socially responsible investments based on the Global Compact Compliance Service by Sustainalytics, a global leader in sustainability research and analysis (Sustainalytics, 2017). This compliance service provides assessments and complementary reports that motivate the assessments and indicate whether a company is in breach of the United Nations Global Compact principles (UN Global Compact, 2016).

A company is labeled non-compliant if it structurally acts in conflict with one or more of these principles and compliant if it does not. Companies are closely monitored for potential breaches of the UN Global Compact principles. Companies are monitored more thoroughly if they currently have problems or had problems in the past. This includes attention from media, allegations and other controversies related to any of the ten principles. Only stocks of compliant companies are indicated as socially responsible stocks. For each stock that is in the investable universe, the bank provides information to its customers on whether it is socially responsible or not, as well as the accompanying assessment that explains why it is (not) socially responsible.

About half the traded stocks are considered socially responsible. With the above definition of socially responsible investors, this results in $21 \%$ of the estimation sample investors being socially responsible. As the socially responsible investors trade less on average, this relates to about $11 \%$ of the observations in our sample. The identification of socially responsible stocks is very stable over our sample period, so we do not expect this to influence our results. ${ }^{5}$

\subsection{Sample construction}

We use transaction data provided by a large multinational full service retail and business bank from the Netherlands. Several studies use data from the Dutch SRI market (e.g. Riedl and Smeets, forthcoming; Bauer and Smeets, 2015; Scholtens, 2005), which is relatively large for a country the size of the Netherlands: The total assets under management involved in SRI in the Netherlands are about 4.4 trillion Euros (EUROSIF, 2016) compared to 8.7 trillion Euros in the United States (SIF, 2016).

Our dataset contains all transactions and positions in stocks by active retail investors in 2015. Trades in the month December are excluded, as this month is characterized by tax-driven trading (Odean, 1998). A retail investor is an investor who manages

\footnotetext{
4 In the few cases investors buy and sell in the same period stocks that are not socially responsible, they are also considered to be conventional investors. So a conventional investor could hold or trade socially responsible stocks, whereas an SRI investor never holds or trades conventional stocks.

5 All our results are robust to using the SRI information from year $t-1$ instead of year $t$.
}

his or her own portfolio. Chang et al. (2016) show the disposition effect only applies to non-delegated assets, so we exclude investors who have asset managers or investment advisors. Following the literature (Dhar and Zhu, 2006; Frino et al., 2015), we only include active investors, defined as having at least 10 transactions in 2015. These restrictions are imposed to focus on the investors that actively react to gains or losses in their portfolio. All investors have the same type of account and accounts closed in 2015 are included to prevent survivorship bias.

For each investor, the transaction data contains a unique identifier, all sale and purchase records including date of trade, price, quantity, an indication of which stocks are socially responsible, the ISIN code of the stock and control variables. Multiple buys or sales on the same day for the same investor are aggregated. The ISIN code is used to match stocks' high and low prices, because the transaction data only contains prices at the time of a trade. These additional daily stock prices are obtained from Thompson Datastream. All prices are in currency of issue.

We retrieve investment positions and transactions for every investor and for every day on which a transaction is made. Investors with a single stock in their portfolio during 2015 are excluded. The transaction data is combined with end-of-month positions comprising all stocks in investors' portfolios for the months January up to and including November. The positions data also contains the average buying price for each investor for each stock, which is based on the full price history of the investor holding a particular stock.

Because of the restrictions mentioned above, the transaction data contains 210,230 unique transactions. After matching the investor's positions to each transaction, the data consists of a total of 890,958 records. The data consists of all different stocks investors either trade or hold for every transaction day. Investors do not trade on a daily basis, so we do not observe trades for each investor for each day.

Initially there are 6,924 investors in the dataset, of which 1,717 socially responsible investors (i.e. investors investing $100 \%$ in socially responsible stocks). For every transaction day all stocks in the investor's portfolio are matched to the high and low stock prices of that day. Stock price data is missing for a few stocks, so during this matching procedure some observations are lost: Starting with 964 unique ISINs (of which 494 are socially responsible stocks), 919 are matched to their high and low prices. ${ }^{6}$

The missing high and low price data excludes 65,053 observations in total, of which 7,674 are from socially responsible investors. For the other (matched) 825,881 observations, the realized gains, realized losses, paper gains and paper losses are calculated and aggregated by transaction day. This results in 132,698 investor-transaction days, for which the proportion of realized gains and the proportion of realized losses are calculated.

Not every investor-transaction day results in a Proportion of Gains (Losses) Realized, because not every investor-transaction day has both Realized Gains (Losses) and Paper Gains (Losses). In our main analyses, the disposition effect is only defined if both the Proportion of Gains Realized and Proportion of Losses Realized are defined. This results in a sample with 74,653 observations on 5,974 investors of which 1,197 are socially responsible investors (i.e. investors investing $100 \%$ in socially responsible stocks).

\subsection{Methodology}

To test whether the disposition effect is greater for socially responsible investors, we estimate the following equation:

$D E_{i t}=\alpha+\beta_{1} S_{R I}+\beta_{2} X_{i t}+\epsilon_{i t}$

\footnotetext{
6 of the 45 non-matched ISINs, 5 are from socially responsible stocks. The 45 non-matching stocks are rarely traded, so we do not expect any bias from excluding
} these stocks. 
where $i$ is the individual investor and $t$ is the transaction day. $D E$ is the disposition effect as defined above. In a robustness check we consider alternative definitions of the disposition effect. SRI is an indicator variable equal to one if an investor invests $100 \%$ in socially responsible stocks. In an additional analysis, we include the continuous variable SRI\% defined as the percentage of the portfolio (in terms of market value) allocated to socially responsible stocks. Based on this variable, we also consider variables that equal SRI\% if this percentage is higher than a certain threshold percentage (e.g. 95\%) and zero otherwise. $X$ is a matrix containing control variables and $\epsilon$ is the error term. Robust standard errors are clustered at the investor level.

We include several portfolio and demographic control variables, most of them commonly found in the disposition effect literature (Odean, 1998; Dhar and Zhu, 2006; Frino et al., 2015). A number of investor control variables are retrieved from a mandatory, bank-administered questionnaire completed by investors when they open their account.

We include Sophistication because we expect that the reliance on reference prices to judge the value of investments is influenced by investment knowledge. More knowledgeable investors are likely to rely less on reference prices, so investor sophistication is expected to be negatively related to the disposition effect (Feng and Seasholes, 2005; Dhar and Zhu, 2006). Sophistication is retrieved from the bank's questionnaire and is defined as knowledge about certain products varying in financial complexity. For every product the investor indicates to have knowledge about, one point is added to the investor sophistication score, adding up to a maximum score of 9 .

Transactions is the total number of investor transactions. Like Dhar and Zhu, (2006) we use Transactions to proxy for investors' trading experience (List, 2003, 2004). Trading experience can reduce the endowment effect and the reluctance to trade (Novemsky and Kahneman, 2005), so the number of transactions is expected to be negatively related to the disposition effect. Assets held is the value of assets held in millions of Euros. The amount of assets held serves as a proxy for investor wealth. Wealthier investors have more at stake, possibly hire external financial advisers and are therefore less likely to display the disposition effect (Dhar and Zhu, 2006). Because the distributions of portfolio size and transactions are heavily skewed, we take natural logarithms: $\operatorname{Ln}$ (Transactions) and $\operatorname{Ln}$ (Assets held). ${ }^{7}$

Investor Age, Gender and Income are investor characteristics retrieved from the bank-administered questionnaire. We take the natural logarithm of Age, which we expect to be negatively related to the disposition effect (Dhar and Zhu, 2006). Gender is an indicator variable equal to one if an investor is male and zero otherwise. For similar reasons as investor wealth, Income is expected to be negatively related to the disposition effect (Dhar and Zhu, 2006). We take the natural logarithm of income, Ln(Income), which is retrieved from the bank-administered questionnaire. The field Income is not mandatory, so it has a substantial number of missing observations.

\subsection{Summary statistics}

Table 1 provides summary statistics for the estimation sample. Consistent with previous research (Odean, 1998), the average disposition effect is positive and equals $11 \%$, but with a standard deviation of $42 \%$ it shows quite some variability. ${ }^{8}$ The average

\footnotetext{
7 We actually take the natural logarithm of $1+$ Assets held to prevent losing negative values. The small negative values in Assets held are likely to be associated with investors winding down their investment accounts.

8 An unreported $t$-test shows that the average disposition effect is significantly greater than zero.
}

Table 1

Summary statistics.

\begin{tabular}{|c|c|c|c|c|c|}
\hline & Mean & SD & Min & Max & $N$ \\
\hline \multicolumn{6}{|l|}{ Dependent variables } \\
\hline $\mathrm{DE}=\mathrm{PGR}-\mathrm{PLR}$ & 0.11 & 0.42 & -1.00 & 1.00 & 74,653 \\
\hline $\mathrm{I}(\mathrm{DE}>0)$ & 0.35 & 0.48 & 0.00 & 1.00 & 74,653 \\
\hline $\mathrm{DE}=(1+\mathrm{PRG}) /(1+\mathrm{PRL})$ & 1.14 & 0.37 & 0.50 & 2.00 & 74,653 \\
\hline $\mathrm{DE}=(\mathrm{RG}-\mathrm{PG}) /(\mathrm{RL}+\mathrm{PL})$ & -058 & 1.08 & -5.33 & 1.00 & 74,653 \\
\hline $\mathrm{DE}=\mathrm{RG} / \mathrm{RL}-\mathrm{PG} / \mathrm{PL}$ & -040 & 1.01 & -5.00 & 2.00 & 17,711 \\
\hline \multicolumn{6}{|l|}{ Independent variables } \\
\hline SRI & 0.11 & 0.31 & 0.00 & 1.00 & 74,653 \\
\hline Sophistication & 1.31 & 1.75 & 0.00 & 9.00 & 74,653 \\
\hline Ln(Transactions) & 3.81 & 0.93 & 2.40 & 6.77 & 74,653 \\
\hline Transactions & 73.43 & 95.00 & 11.00 & 872.00 & 74,653 \\
\hline Ln(Assets held) & 3.88 & 1.50 & -6.91 & 9.97 & 74,653 \\
\hline Assets held & 0.12 & 0.28 & -0.06 & 21.28 & 74,653 \\
\hline Gender & 0.90 & 0.30 & 0.00 & 1.00 & 74,653 \\
\hline Ln(Age) & 4.07 & 0.26 & 2.77 & 4.50 & 74,653 \\
\hline Age & 60.35 & 13.63 & 16.00 & 90.00 & 74,653 \\
\hline Ln(Income) & 9.36 & 3.61 & 0.00 & 13.46 & 48,930 \\
\hline Income & 49.20 & 47.88 & 0.00 & 700.00 & 48,930 \\
\hline SRI\% & 0.82 & 0.13 & 0.00 & 1.00 & 74,653 \\
\hline SRI\% if SRI\% $\geq 95 \%$ & 0.15 & 0.36 & 0.00 & 1.00 & 74,653 \\
\hline SRI\% if SRI\% $\geq 90 \%$ & 0.26 & 0.43 & 0.00 & 1.00 & 74,653 \\
\hline SRI\% if SRI\% $\geq 85 \%$ & 0.42 & 0.46 & 0.00 & 1.00 & 74,653 \\
\hline SRI\% if SRI\% $\geq 80 \%$ & 0.56 & 0.44 & 0.00 & 1.00 & 74,653 \\
\hline SRI\% if SRI\% $\geq 75 \%$ & 0.67 & 0.38 & 0.00 & 1.00 & 74,653 \\
\hline SRI\% if SRI\% $<75 \%$ & 0.15 & 0.28 & 0.00 & 0.75 & 74,653 \\
\hline
\end{tabular}

Notes: PGR is the Proportion of Gains Realized, PLR is the Proportion of Losses Realized and $D E$ is the Disposition Effect, calculated based on the number of realized gains (RG), realized losses (RL), paper gains (PG), and paper losses (PL). $I(D E>0)$ is an indicator variable equal to one when the disposition effect $(D E=P G R-P L R)$ is positive; zero otherwise. SRI is an indicator variable equal to one if an investor invests $100 \%$ in socially responsible stocks; zero otherwise. Sophistication is the investor's sophistication score. The variable Transactions is the total number of transactions over 2015. Assets held is the value of assets held in millions of Euros, Gender is a indicator variable equal to one if an investor is male; zero otherwise, Age is the age of the investor in years, Income is the self-reported gross yearly investor income in thousands of Euros. SRI\% indicates the percentage of the portfolio (in terms of value) allocated to socially responsible stocks. SRI\% if SRI\% $\geq X \%$ are variables equal to SRI\% when investors allocate X\% or more to SRI stocks; zero otherwise. SRI\% if SRI\% < 75\% equals SRI\% when investors allocate less than $75 \%$ to SRI stocks; zero otherwise.

disposition effect is relatively low, which could be due to the fact that our sample only covers one year of trading. The disposition effect of the group of socially responsible investors is $19 \%{ }^{9}$

The SRI\% is the percentage of stocks in the transaction data that concerns socially responsible stocks. The average SRI\% is $82 \%$, which is relatively high. However, only for $11 \%$ of the observations do we observe investors that invest $100 \%$ in socially responsible stocks. The majority of investors appear to have at least $75 \%$ of their portfolio holdings in socially responsible stocks.

With an average sophistication level of 1.31 , the average investor is relatively unsophisticated, performs about 73 transactions per year, holds on average 120,000 Euro in assets, has a selfreported yearly income of about 49 thousand Euro and is 60 years old. $90 \%$ of the investors in our sample are male. Table A. 1 provides summary statistics split according to whether investors are socially responsible. By comparison, the average socially responsible investor in our estimation sample has a sophistication level of 0.87 , performs about 47 transactions per year, holds on average 70,000 Euro in assets, has a self-reported income of about 46 thousand Euro and is 59 years old. $88 \%$ of the socially responsible investors in our sample are male.

\footnotetext{
9 This summary statistic is derived from Table A. 1 and an unreported $t$-test shows that the average disposition effect of socially responsible investors is significantly different from that of conventional investors.
} 
Table 2

Main results: Disposition effect.

\begin{tabular}{|c|c|c|c|c|c|c|c|}
\hline & (1) & (2) & (3) & (4) & (5) & (6) & (7) \\
\hline SRI & $\begin{array}{l}0.079^{* * * *} \\
(0.011)\end{array}$ & $\begin{array}{l}0.076^{* * * *} \\
(0.011)\end{array}$ & $\begin{array}{l}0.065^{\text {****}} \\
(0.011)\end{array}$ & $\begin{array}{l}0.056^{* * *} \\
(0.011)\end{array}$ & $\begin{array}{l}0.055^{* * *} \\
(0.011)\end{array}$ & $\begin{array}{l}0.056^{* * *} \\
(0.011)\end{array}$ & $\begin{array}{l}0.037^{* *} \\
(0.014)\end{array}$ \\
\hline Sophistication & & $\begin{array}{l}-0.008^{* * *} \\
(0.001)\end{array}$ & $\begin{array}{l}-0.009^{* * *} \\
(0.001)\end{array}$ & $\begin{array}{l}-0.005^{* * *} \\
(0.002)\end{array}$ & $\begin{array}{l}-0.005^{* * * *} \\
(0.002)\end{array}$ & $\begin{array}{l}-0.004^{* * *} \\
(0.002)\end{array}$ & $\begin{array}{l}-0.004^{* *} \\
(0.002)\end{array}$ \\
\hline Ln(Transactions) & & & $\begin{array}{l}-0.025^{* * *} \\
(0.003)\end{array}$ & $\begin{array}{l}-0.023^{* * *} \\
(0.003)\end{array}$ & $\begin{array}{l}-0.023^{* * *} \\
(0.003)\end{array}$ & $\begin{array}{l}-0.022^{* * *} \\
(0.003)\end{array}$ & $\begin{array}{l}-0.019^{* * *} \\
(0.004)\end{array}$ \\
\hline Ln(Assets held) & & & & $\begin{array}{l}-0.020^{* * *} \\
(0.002)\end{array}$ & $\begin{array}{l}-0.020^{* * *} \\
(0.002)\end{array}$ & $\begin{array}{l}-0.019^{* * *} \\
(0.002)\end{array}$ & $\begin{array}{l}-0.022^{* * *} \\
(0.003)\end{array}$ \\
\hline Gender & & & & & $\begin{array}{l}-0.018^{*} \\
(0.010)\end{array}$ & $\begin{array}{l}-0.017^{*} \\
(0.010)\end{array}$ & $\begin{array}{l}-0.015 \\
(0.012)\end{array}$ \\
\hline Ln(Age) & & & & & & $\begin{array}{l}-0.032^{* * *} \\
(0.012)\end{array}$ & $\begin{array}{l}-0.026^{*} \\
(0.015)\end{array}$ \\
\hline Ln(Income) & & & & & & & $\begin{array}{l}-0.001 \\
(0.001)\end{array}$ \\
\hline Constant & $\begin{array}{l}0.106^{* * *} \\
(0.003)\end{array}$ & $\begin{array}{l}0.116^{* * *} \\
(0.004)\end{array}$ & $\begin{array}{l}0.214^{* * *} \\
(0.013)\end{array}$ & $\begin{array}{l}0.282^{* * *} \\
(0.014)\end{array}$ & $\begin{array}{l}0.297^{* * *} \\
(0.016)\end{array}$ & $\begin{array}{l}0.418^{* * * *} \\
(0.047)\end{array}$ & $\begin{array}{l}0.401^{* * *} \\
(0.059)\end{array}$ \\
\hline Observations & 74,653 & 74,653 & 74,653 & 74,653 & 74,653 & 74,653 & 48,930 \\
\hline$R^{2}$ & 0.004 & 0.005 & 0.008 & 0.012 & 0.013 & 0.013 & 0.013 \\
\hline$N$ investors & 5,974 & 5,974 & 5,974 & 5,974 & 5,974 & 5,974 & 3,840 \\
\hline$N$ SRI investors & 1,197 & 1,197 & 1,197 & 1,197 & 1,197 & 1,197 & 731 \\
\hline
\end{tabular}

Notes: This table reports estimates of Eq. (4). All variable definitions are provided in Table 1. $N$ investors and $N$ SRI investors indicate, respectively, the total number of investors and the number of investors that invest $100 \%$ in socially responsible stocks in each estimation sample. Robust standard errors are clustered at the investor level and are reported in parentheses and ${ }^{* * *},{ }^{* *}$, and ${ }^{*}$ correspond to the $1 \%, 5 \%$, and $10 \%$ level of significance, respectively.

\section{Results}

\subsection{Main results}

Table 2 reports the main results of our regressions. The disposition effect varies at the individual level (Dhar and Zhu, 2006) and socially responsible investors differ from conventional investors. ${ }^{10}$ Therefore, we add control variables one by one to assess the relative importance of investors being socially responsible investors.

The effect of the SRI indicator variable, indicating investors invest $100 \%$ of their portfolio in socially responsible stocks, is positive and statistically significant in all specifications, which confirms Hypothesis 1. Column (1) shows socially responsible investors have a disposition effect that is 7.9 percentage points higher than that of conventional investors.

The size of the effect of SRI drops ones we control for the number of transactions and the amount of assets held. It drops again when we control for investor income, but this could also be due to the smaller sample size we have once we control for investor income. However, even in the most restrictive specification, socially responsible investors have a disposition effect that is 3.7 percentage points higher than that of conventional investors. This is still sizable compared to an average disposition effect of $11 \%$.

In line with Dhar and Zhu (2006), greater investor sophistication is associated with a lower disposition effect. The size of the effect is relatively modest: One point increase in investor sophistication (on a scale of one to nine) is associated with a disposition effect that is $0.4-0.9$ percentage points lower.

The logarithm of transactions is included to capture investor experience and shows the expected negative sign. This variable is significant at a $1 \%$ level for all specifications. Consistent with existing literature (List, 2003, 2004; Dhar and Zhu, 2006) trading experience is negatively associated with the disposition effect. Doubling the number of transactions (i.e. an increase of 100\%) is associated with a disposition effect that is $1.9-2.5$ percentage points lower.

Investor wealth, as proxied by the logarithm of the value of Assets held, is significantly negatively related to the disposition

\footnotetext{
10 See summary statistics in Table A.1.
}

effect. The size of the effect is similar to that of the number of transactions: doubling the size of assets held, decreases the disposition effect by 1.9-2.2 percentage points. This supports the notion that more wealthy investors are less subject to the disposition effect. Male investors appear to display a smaller disposition effect than female investors, although gender is only significant at a $10 \%$ level in Column (5) and (6). Consistent with Dhar and Zhu, (2006), older investors display a greater disposition effect. Doubling the age, say from 30-60, decreases the disposition effect with $2.6-3.2$ percentage points.

In sum, results on our control variables are consistent with existing literature and socially responsible investors are associated with a greater disposition effect, when socially responsible investors are defined as investors that invest only in socially responsible stocks. Next, we will relax this definition of socially responsible investors.

\subsection{Alternative SRI measures}

To test Hypothesis 2, we first regress the disposition effect on the continuous variable SRI\% which indicates the percentage of the portfolio (in terms of market value) allocated to socially responsible stocks. If socially responsible stock characteristics are driving the disposition effect, we would expect SRI\% to be positively related to the disposition effect. Alternatively, if it is the trading behavior of socially responsible investors - identifying themselves as such - that is driving this result, we would expect there to be some lower threshold of the percentage allocated to SRI for investors to still identify themselves as socially responsible. Therefore, we construct several variables that are equal to SRI\% when SRI\% is greater than or equal than X\%, where X\% varies from $95 \%$ to $75 \%$ in steps of $5 \%$, and is zero otherwise. ${ }^{11}$ Finally, we also include a variable equal to SRI\% when SRI\% is smaller than 75\% and zero otherwise.

Table 3 presents the results. Column (1) shows that the effect of the continuous variable SRI\% is positive, but small and statistically insignificant. For comparison purposes, Column (2) corresponds to Column (6) from Table 2. It includes SRI\% if SRI\% $=100 \%$, which

\footnotetext{
11 Coding the variables to be equal to 1 instead of equal to SRI\% when SRI is greater than or equal to $\mathrm{X} \%$ provides results that are very similar.
} 
Table 3

Alternative SRI definitions according to percentage of SRI stocks.

\begin{tabular}{|c|c|c|c|c|c|c|c|c|}
\hline & (1) & (2) & (3) & (4) & (5) & (6) & (7) & (8) \\
\hline SRI\% & $\begin{array}{l}0.013 \\
(0.025)\end{array}$ & & & & & & & \\
\hline SRI\% if SRI $\%=100 \%$ & & $\begin{array}{l}0.056^{* * * *} \\
(0.011)\end{array}$ & & & & & & \\
\hline SRI\% if SRI\% $\geq 95 \%$ & & & $\begin{array}{l}0.051^{* * *} \\
(0.010)\end{array}$ & & & & & \\
\hline SRI\% if SRI\% $\geq 90 \%$ & & & & $\begin{array}{l}0.027^{* * * *} \\
(0.007)\end{array}$ & & & & \\
\hline SRI\% if SRI\% $\geq 85 \%$ & & & & & $\begin{array}{l}0.019^{* * *} \\
(0.006)\end{array}$ & & & \\
\hline SRI\% if SRI\% $\geq 80 \%$ & & & & & & $\begin{array}{l}0.005 \\
(0.007)\end{array}$ & & \\
\hline SRI\% if SRI\% $\geq 75 \%$ & & & & & & & $\begin{array}{l}0.003 \\
(0.008)\end{array}$ & \\
\hline SRI\% if SRI\% < 75\% & & & & & & & & $\begin{array}{l}-0.002 \\
(0.010)\end{array}$ \\
\hline Sophistication & $\begin{array}{l}-0.005^{* * *} \\
(0.002)\end{array}$ & $\begin{array}{l}-0.004^{* * *} \\
(0.002)\end{array}$ & $\begin{array}{l}-0.004^{* * *} \\
(0.002)\end{array}$ & $\begin{array}{l}-0.004^{* * *} \\
(0.002)\end{array}$ & $\begin{array}{l}-0.004^{* * *} \\
(0.002)\end{array}$ & $\begin{array}{l}-0.005^{* * *} \\
(0.002)\end{array}$ & $\begin{array}{l}-0.005^{* * *} \\
(0.002)\end{array}$ & $\begin{array}{l}-0.005^{* * *} \\
(0.002)\end{array}$ \\
\hline Ln(Transactions) & $\begin{array}{l}-0.025^{* * * *} \\
(0.003)\end{array}$ & $\begin{array}{l}-0.022^{* * *} \\
(0.003)\end{array}$ & $\begin{array}{l}-0.023^{* * *} \\
(0.004)\end{array}$ & $\begin{array}{l}-0.024^{* * *} \\
(0.004)\end{array}$ & $\begin{array}{l}-0.024^{* * * *} \\
(0.003)\end{array}$ & $\begin{array}{l}-0.025^{* * * *} \\
(0.003)\end{array}$ & $\begin{array}{l}-0.025^{* * *} \\
(0.003)\end{array}$ & $\begin{array}{l}-0.025^{* * *} \\
(0.003)\end{array}$ \\
\hline Ln(Assets held) & $\begin{array}{l}-0.020^{* * * *} \\
(0.002)\end{array}$ & $\begin{array}{l}-0.019^{* * *} \\
(0.002)\end{array}$ & $\begin{array}{l}-0.019^{* * *} \\
(0.002)\end{array}$ & $\begin{array}{l}-0.020^{* * *} \\
(0.002)\end{array}$ & $\begin{array}{l}-0.020^{* * * *} \\
(0.002)\end{array}$ & $\begin{array}{l}-0.020^{* * * *} \\
(0.002)\end{array}$ & $\begin{array}{l}-0.020^{* * *} \\
(0.002)\end{array}$ & $\begin{array}{l}-0.020^{* * *} \\
(0.002)\end{array}$ \\
\hline Gender & $\begin{array}{l}-0.017^{*} \\
(0.010)\end{array}$ & $\begin{array}{l}-0.017^{*} \\
(0.010)\end{array}$ & $\begin{array}{l}-0.017^{*} \\
(0.010)\end{array}$ & $\begin{array}{l}-0.017^{*} \\
(0.010)\end{array}$ & $\begin{array}{l}-0.017^{*} \\
(0.010)\end{array}$ & $\begin{array}{l}-0.017^{*} \\
(0.010)\end{array}$ & $\begin{array}{l}-0.018^{*} \\
(0.010)\end{array}$ & $\begin{array}{l}-0.018^{*} \\
(0.010)\end{array}$ \\
\hline Ln(Age) & $\begin{array}{l}-0.031^{* * * *} \\
(0.012)\end{array}$ & $\begin{array}{l}-0.032^{* * *} \\
(0.012)\end{array}$ & $\begin{array}{l}-0.031^{* * *} \\
(0.012)\end{array}$ & $\begin{array}{l}-0.031^{* * *} \\
(0.012)\end{array}$ & $\begin{array}{l}-0.032^{* * *} \\
(0.012)\end{array}$ & $\begin{array}{l}-0.031^{* * *} \\
(0.012)\end{array}$ & $\begin{array}{l}-0.031^{* * *} \\
(0.012)\end{array}$ & $\begin{array}{l}-0.031^{* * * *} \\
(0.012)\end{array}$ \\
\hline Constant & $\begin{array}{l}0.427^{* * *} \\
(0.050)\end{array}$ & $\begin{array}{l}0.418^{* * * *} \\
(0.047)\end{array}$ & $\begin{array}{l}0.417^{* * *} \\
(0.047)\end{array}$ & $\begin{array}{l}0.425^{* * *} \\
(0.047)\end{array}$ & $\begin{array}{l}0.431^{* * *} \\
(0.047)\end{array}$ & $\begin{array}{l}0.435^{* * *} \\
(0.047)\end{array}$ & $\begin{array}{l}0.435^{* * *} \\
(0.047)\end{array}$ & $\begin{array}{l}0.437^{* * *} \\
(0.047)\end{array}$ \\
\hline Observations & 74,653 & 74,653 & 74,653 & 74,653 & 74,653 & 74,653 & 74,653 & 74,653 \\
\hline$R^{2}$ & 0.011 & 0.013 & 0.013 & 0.012 & 0.012 & 0.011 & 0.011 & 0.011 \\
\hline$N$ investors & 5,974 & 5,974 & 5,974 & 5,974 & 5,974 & 5,974 & 5,974 & 5,974 \\
\hline$N$ SRI investors & NA & 1,197 & 1,405 & 2,031 & 2,904 & 3,754 & 4,434 & 1,533 \\
\hline
\end{tabular}

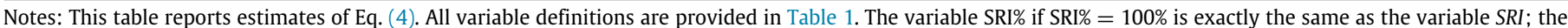

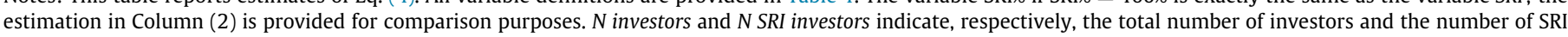

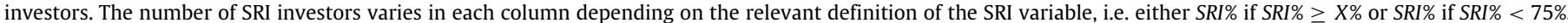

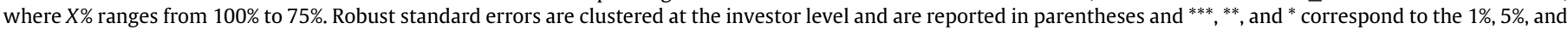
$10 \%$ level of significance, respectively.

Table 4

Probit disposition effect.

\begin{tabular}{|c|c|c|c|c|c|c|c|}
\hline & (1) & (2) & (3) & (4) & (5) & (6) & (7) \\
\hline SRI & $\begin{array}{l}0.205^{* * *} \\
(0.024)\end{array}$ & $\begin{array}{l}0.190^{* * * *} \\
(0.024)\end{array}$ & $\begin{array}{l}0.220^{* * * *} \\
(0.025)\end{array}$ & $\begin{array}{l}0.188^{* * *} \\
(0.025)\end{array}$ & $\begin{array}{l}0.187^{* * *} \\
(0.025)\end{array}$ & $\begin{array}{l}0.188^{* * *} \\
(0.025)\end{array}$ & $\begin{array}{l}0.154^{* * *} \\
(0.032)\end{array}$ \\
\hline Sophistication & & $\begin{array}{l}-0.030^{* * *} \\
(0.005)\end{array}$ & $\begin{array}{l}-0.027^{* * *} \\
(0.005)\end{array}$ & $\begin{array}{l}-0.013^{* * * *} \\
(0.005)\end{array}$ & $\begin{array}{l}-0.012^{* * *} \\
(0.005)\end{array}$ & $\begin{array}{l}-0.010^{* *} \\
(0.005)\end{array}$ & $\begin{array}{l}-0.010^{*} \\
(0.006)\end{array}$ \\
\hline Ln(Transactions) & & & $\begin{array}{l}0.074^{* * *} \\
(0.009)\end{array}$ & $\begin{array}{l}0.080^{* * * *} \\
(0.010)\end{array}$ & $\begin{array}{l}0.081^{* * *} \\
(0.010)\end{array}$ & $\begin{array}{l}0.083^{* * *} \\
(0.010)\end{array}$ & $\begin{array}{l}0.084^{* * * *} \\
(0.013)\end{array}$ \\
\hline Ln(Assets held) & & & & $\begin{array}{l}-0.070^{* * *} \\
(0.006)\end{array}$ & $\begin{array}{l}-0.070^{* * * *} \\
(0.006)\end{array}$ & $\begin{array}{l}-0.067^{* * *} \\
(0.006)\end{array}$ & $\begin{array}{l}-0.072^{* * *} \\
(0.008)\end{array}$ \\
\hline Gender & & & & & $\begin{array}{l}-0.054 \\
(0.028)\end{array}$ & $\begin{array}{l}-0.051^{*} \\
(0.028)\end{array}$ & $\begin{array}{c}-0.043 \\
(0.039)\end{array}$ \\
\hline Ln(Age) & & & & & & $\begin{array}{l}-0.097^{* * *} \\
(0.031)\end{array}$ & $\begin{array}{c}-0.050 \\
(0.043)\end{array}$ \\
\hline Ln(Income) & & & & & & & $\begin{array}{l}-0.005^{*} \\
(0.003)\end{array}$ \\
\hline Constant & $\begin{array}{l}-0.422^{* * *} \\
(0.009)\end{array}$ & $\begin{array}{l}-0.381^{* * *} \\
(0.011)\end{array}$ & $\begin{array}{l}-0.670^{* * * *} \\
(0.036)\end{array}$ & $\begin{array}{l}-0.441^{* * * *} \\
(0.041)\end{array}$ & $\begin{array}{l}-0.395^{* * *} \\
(0.045)\end{array}$ & $\begin{array}{l}-0.025 \\
(0.128)\end{array}$ & $\begin{array}{l}-0.159 \\
(0.175)\end{array}$ \\
\hline Observations & 74,653 & 74,653 & 74,653 & 74,653 & 74,653 & 74,653 & 48,930 \\
\hline Pseudo $R^{2}$ & 0.0020 & 0.0033 & 0.0054 & 0.0102 & 0.0103 & 0.0106 & 0.0110 \\
\hline$N$ investors & 5,974 & 5,974 & 5,974 & 5,974 & 5,974 & 5,974 & 3,840 \\
\hline$N$ SRI investors & 1,197 & 1,197 & 1,197 & 1,197 & 1,197 & 1,197 & 731 \\
\hline
\end{tabular}

Notes: This table reports estimates of Eq. (4) where the dependent variable is replaced by I(DE $>0)$ and the equation is estimated as a Probit. Reported coefficients are marginal effects. All variable definitions are provided in Table $1 . N$ investors and N SRI investors indicate, respectively, the total number of investors and the number of investors that invest $100 \%$ in socially responsible stocks in each estimation sample. Robust standard errors are clustered at the investor level and are reported in parentheses and ${ }^{* * *},{ }^{* *}$, and ${ }^{*}$ correspond to the $1 \%, 5 \%$, and $10 \%$ level of significance, respectively.

is the same variable as SRI because we express all percentages as fractions. Next, we make the identification of socially responsible investors progressively more lenient by requiring them to hold less stocks and still be considered socially responsible investors. Starting from Column (4) the effect size of the SRI variable, SRI\% if $S R I \% \geq 90 \%$, equals 0.027 and reduces further in Column (5) to 
Table 5

Alternative disposition effect measures.

\begin{tabular}{llll}
\hline & $(1)$ & $(2)$ & $(3)$ \\
\hline SRI & $0.079^{* * * *}$ & $0.292^{* * * *}$ & $0.159^{* * *}$ \\
Sophistication & $(0.010)$ & $(0.030)$ & $(0.027)$ \\
& $-0.003^{* * *}$ & $-0.024^{* * * *}$ & $-0.032^{* * *}$ \\
Ln(Transactions) & $(0.001)$ & $(0.009)$ & $(0.009)$ \\
& $-0.011^{* * *}$ & $0.060^{* * *}$ & $0.050^{* * *}$ \\
Ln(Assets held) & $(0.003)$ & $(0.016)$ & $(0.016)$ \\
& $-0.026^{* * *}$ & $-0.146^{* * *}$ & $-0.059^{* * *}$ \\
Gender & $(0.002)$ & $(0.010)$ & $(0.009)$ \\
& -0.013 & -0.051 & -0.025 \\
Ln(Age) & $(0.009)$ & $(0.038)$ & $(0.034)$ \\
& $-0.041^{* * * *}$ & -0.075 & $-0.164^{* * *}$ \\
Constant & $(0.011)$ & $(0.046)$ & $(0.046)$ \\
& $1.458^{* * *}$ & -0.100 & 0.305 \\
Observations & $(0.043)$ & $(0.185)$ & $(0.198)$ \\
$R$-squared & 74,653 & 74,653 & 17,711 \\
$N$ investors & 0.024 & 0.051 & 0.022 \\
$N$ SRI investors & 5,974 & 5,974 & 4,124 \\
\end{tabular}

Notes: This table reports estimates of Eq. (4) with alternative disposition effect measures as dependent variable. In Column (1) the disposition effect is calculated as $(1+P R G) /(1+P R L)$. In Column (2) the disposition effect is calculated as $(R G-$ $P G) /(R L+P L)$ and in Column (3) the disposition effect is calculated as $(R G / R L-$ $P G / P L)$. The latter two are winsorized at the $1 \%$ level. All variable definitions are provided in Table $1 . N$ investors and N SRI investors indicate, respectively, the total number of investors and the number of investors that invest $100 \%$ in socially responsible stocks in each estimation sample. Robust standard errors are clustered at the investor level and are reported in parentheses and ${ }^{* * *},{ }^{* *}$, and * correspond to the $1 \%, 5 \%$, and $10 \%$ level of significance, respectively.

0.019. In Column (6) the variable SRI\% if SRI\% $\geq 80 \%$ is no longer significant, which implies that only if we identify socially responsible investors as having at least $85 \%$ of their portfolio allocated to socially responsible stocks do we find evidence of them displaying a greater disposition effect. This is further corroborated by the insignificant results on the SRI variables in Column (7) and (8).

Therefore, we reject Hypothesis 2 and find no evidence that investors display a greater disposition effect when a bigger part of their portfolio consists of socially responsible stocks. That is, only starting at a relatively high threshold does the disposition effect seem to be increasing in the allocation to socially responsible stocks. This suggests that the disposition effect is more likely to be driven by socially responsible investors identifying themselves as such and behaving differently from conventional investors, than characteristics of socially responsible stocks.

\subsection{Robustness tests}

In this section we perform several robustness tests to verify our main results from Table 2. First, we test whether outliers in our main disposition effect measure are driving our results. Second, we consider several alternative disposition effect measures. Third, we use propensity score matching to test whether our results still hold when we match socially responsible investors with conventional investors based on observable characteristics.

\subsubsection{Distributional properties}

The disposition effect is by definition bounded between minus one and one and is not normally distributed. Like in Dhar and Zhu (2006) the DE distribution shows spikes at the extremes of -1 and 1. Because results could be influenced by these extreme values and cut-offs, we perform an additional robustness test: Like Dhar and Zhu (2006) we create a new indicator variable, $I(D E>0)$, that equals one if the disposition effect is positive and zero otherwise. This ensures the peaks at the extreme values are normalized and regression output is easier to interpret.

Table 4 shows marginal effects for probit regressions of $I(D E>$ 0 ) on our SRI variable. SRI is positive and significant in all specifications. Socially responsible investors are about $15 \%-20 \%$ more likely to exhibit a disposition effect. Comparable to the main results in Table 2, more sophisticated investors are less to display the disposition effect. Also the amount of assets held makes investors less likely to display the disposition effect, however, surprisingly the number of transactions is now positively associated with the likelihood of exhibiting the disposition effect. Like in Table 2, men appear to be less subject to the disposition effect and also age and income are negatively related to the disposition effect.

\subsubsection{Alternative disposition effect measures}

We consider three alternative disposition effect measures. The first measure is the ratio of PRG to PRL, which is less influenced

Table 6

Propensity score matching: SRI versus conventional investors.

\begin{tabular}{llllllll}
\hline & $(1)$ & $(2)$ & $(3)$ & $(4)$ & $(5)$ & $(6)$ & $(7)$ \\
\hline SRI & $0.059^{* * *}$ & $0.059^{* * *}$ & $0.060^{* * *}$ & $0.056^{* * *}$ & $0.056^{* * *}$ & $0.056^{* * * *}$ & $0.028^{* *}$ \\
& $(0.013)$ & $(0.013)$ & $(0.012)$ & $(0.012)$ & $(0.012)$ & $(0.012)$ & $(0.016)$ \\
Sophistication & & $-0.008^{*}$ & $-0.008^{*}$ & -0.002 & -0.001 & -0.000 & 0.001 \\
& & $(0.004)$ & $(0.005)$ & $(0.005)$ & $(0.005)$ & $(0.005)$ & $(0.006)$ \\
Ln(Transactions) & & & $-0.026^{* * *}$ & $-0.019^{* * *}$ & $-0.019^{* *}$ & $-0.017^{* *}$ & -0.007 \\
& & & $(0.009)$ & $(0.009)$ & $(0.009)$ & $(0.009)$ & $(0.011)$ \\
Ln(Assets held) & & & & $-0.025^{* * *}$ & $-0.025^{* * *}$ & $-0.023^{* * *}$ & $-0.023^{* * *}$ \\
& & & & $(0.005)$ & $(0.005)$ & $(0.005)$ & $(0.007)$ \\
Gender & & & & $-0.032^{*}$ & -0.028 & -0.013 \\
& & & & & $(0.018)$ & $(0.018)$ & $(0.024)$ \\
Ln(Age) & & & & & $-0.063^{* * *}$ & $-0.076^{* * *}$ \\
& & & & & & $(0.022)$ & $(0.033)$ \\
Ln(Income) & & & & & & 0.001 \\
Constant & & & & & & $(0.002)$ \\
& $0.126^{* * * *}$ & $0.133^{* * *}$ & $0.222^{* * *}$ & $0.278^{* * *}$ & $0.306^{* * *}$ & $0.542^{* * *}$ & $0.554^{* * *}$ \\
Observations & $(0.007)$ & $(0.008)$ & $(0.029)$ & $(0.031)$ & $(0.034)$ & $(0.088)$ & $(0.130)$ \\
$R$-Squared & & & & & & & \\
$N$ investors & 20,703 & 20,703 & 20,703 & 20,703 & 20,703 & 20,703 & 12,743 \\
$N$ SRI investors & 0.004 & 0.004 & 0.006 & 0.011 & 0.012 & 0.013 & 0.009 \\
\hline
\end{tabular}

Notes: This table reports estimates of Eq. (4) using propensity score matching based on all control variables except income. All variable definitions are provided in Table 1. $N$ investors and N SRI investors indicate, respectively, the total number of investors and the number of investors that invest $100 \%$ in socially responsible stocks in each estimation sample. Robust standard errors are clustered at the investor level and are reported in parentheses and ${ }^{* * *},{ }^{* *}$, and ${ }^{*}$ correspond to the $1 \%, 5 \%$, and $10 \%$ level of significance, respectively. 
by investors' trading frequency (Odean, 1998). ${ }^{12}$ Second, we use a measure suggested by Weber and Camerer (1998) that is not bounded with respect to trading frequency and size: $(R G-$ $P G) /(R L+P L)$. Third, we use a measure defined as $R G / R L-P G / P L$, which avoids potential scaling bias (Dhar and Zhu, 2006). Like before, these measures are based on the number of realized gains $(\mathrm{RG})$, realized losses (RL), paper gains (PG), and paper losses (PL). Note that the third measure significantly reduces the number of observations. The second and the third measure show large outliers, so we winsorize them at the $1 \%$ level.

Table 5 presents the results for three alternative disposition effect measures. Column (1) show the results when the disposition effect is defined as the ratio of PRG to PRL. Socially responsible investors have a disposition effect that is 0.079 higher than that of conventional investors. Column (2) shows the results when the disposition effect is defined as $(R G-P G) /(R L+P L)$. Socially responsible investors have a disposition effect that is 0.292 higher than that of conventional investors. Finally, Column (3) shows the disposition effect is 0.159 higher for socially responsible investors than for conventional investors, when the disposition effect is defined as $R G / R L-P G / P L$. With the exception of the number of transactions, all control variables show the same signs as in Table 2.

\subsubsection{Matched sample regressions}

As an additional robustness test to control for investor characteristics, all 1,197 SRI investors are one-to-one matched to their closest conventional investor using propensity score matching (Caliendo and Kopeinig, 2008). Following Cuong (2013), we include all the control variables in both the estimation of propensity scores and the outcome equation. ${ }^{13}$ Only matched investors are included in the matched sample regressions, which gives a sample of 2,394 investors. Table A.2 provides summary statistics for the matched sample. A comparison of Tables A.1 and A.2 illustrates to what extent the matched samples are more similar based on observable characteristics.

Matched sample regressions output is presented in Table 6. Results on the SRI variable are qualitatively consistent with the results in Table 2, although the size of the effect is somewhat smaller: Socially responsible investors have a disposition effect that is larger by about 2.8-6.0 percentage points. Except for investor sophistication, the coefficients on most control variables have about the same sign and significance as those in Table 2.

\section{Conclusion}

This paper studies the disposition effect using brokerage data from a large retail bank that provides social responsibility information on stocks to investors. We find evidence for our main proposition that socially responsible investors display a greater disposition effect than conventional investors. This result is robust across different specifications and robustness checks, including defining the disposition effect as a binary variable, alternative definitions of the disposition effect and propensity scores matching socially responsible investors with conventional investors. We control for several individual and portfolio-level characteristics, the results of which are mostly in line with existing literature.

We find the largest differential disposition effect when socially responsible investors invest their entire portfolio in socially responsible stocks. Once we decrease the percentage invested in socially responsible stocks to identify socially responsible investors,

\footnotetext{
12 We add 1 to both the numerator and denominator of this fraction to prevent losing observations when PRG or PRL equals zero.

13 We exclude income as a matching variable, because it contains a substantial number of missing observations.
}

Table A.1

Summary statistics: SRI versus conventional investors.

\begin{tabular}{|c|c|c|c|c|c|}
\hline & Mean & SD & Min & Max & $N$ \\
\hline \multicolumn{6}{|l|}{ Panel A: SRI } \\
\hline \multicolumn{6}{|l|}{ Dependent variables } \\
\hline $\mathrm{DE}=\mathrm{PGR}-\mathrm{PLR}$ & 0.19 & 0.56 & -1.00 & 1.00 & 8,317 \\
\hline $\mathrm{I}(\mathrm{DE}>0)$ & 0.41 & 0.49 & 0.00 & 1.00 & 8,317 \\
\hline $\mathrm{DE}=(1+\mathrm{PRG}) /(1+\mathrm{PRL})$ & 1.23 & 0.47 & 0.50 & 2.00 & 8,317 \\
\hline $\mathrm{DE}=(\mathrm{RG}-\mathrm{PG}) /(\mathrm{RL}+\mathrm{PL})$ & -0.25 & 0.84 & -5.33 & 1.00 & 8,317 \\
\hline $\mathrm{DE}=\mathrm{RG} / \mathrm{RL}-\mathrm{PG} / \mathrm{PL}$ & -0.26 & 0.75 & -5.00 & 2.00 & 2,693 \\
\hline \multicolumn{6}{|l|}{ Independent variables } \\
\hline Sophistication & 0.87 & 1.39 & 0.00 & 9.00 & 8,317 \\
\hline Ln(Transactions) & 3.47 & 0.80 & 2.40 & 6.02 & 8,317 \\
\hline Transactions & 46.94 & 55.39 & 11.00 & 413.00 & 8,317 \\
\hline Ln(Assets held) & 3.33 & 1.48 & -6.91 & 7.42 & 8,317 \\
\hline Assets held & 0.07 & 0.15 & -0.01 & 1.67 & 8,317 \\
\hline Gender & 0.88 & 0.33 & 0.00 & 1.00 & 8,317 \\
\hline Ln(Age) & 4.05 & 0.28 & 2.77 & 4.50 & 8,317 \\
\hline Age & 59.13 & 13.95 & 16.00 & 90.00 & 8,317 \\
\hline Ln(Income) & 8.93 & 3.98 & 0.00 & 13.12 & 5,206 \\
\hline Income & 45.73 & 55.31 & 0.00 & 500.00 & 5,206 \\
\hline \multicolumn{6}{|l|}{ Panel B: Conventional } \\
\hline \multicolumn{6}{|l|}{ Dependent variables } \\
\hline$\overline{\mathrm{DE}}=\mathrm{PGR}-\mathrm{PLR}$ & 0.11 & 0.40 & -1.00 & 1.00 & 66,336 \\
\hline $\mathrm{I}(\mathrm{DE}>0)$ & 0.34 & 0.47 & 0.00 & 1.00 & 66,336 \\
\hline $\mathrm{DE}=(1+\mathrm{PRG}) /(1+\mathrm{PRL})$ & 1.13 & 0.35 & 0.50 & 2.00 & 66,336 \\
\hline $\mathrm{DE}=(\mathrm{RG}-\mathrm{PG}) /(\mathrm{RL}+\mathrm{PL})$ & -0.64 & 1.10 & -5.33 & 1.00 & 66,336 \\
\hline $\mathrm{DE}=\mathrm{RG} / \mathrm{RL}-\mathrm{PG} / \mathrm{PL}$ & -0.43 & 1.04 & -5.00 & 2.00 & 15,018 \\
\hline \multicolumn{6}{|l|}{ Independent variables } \\
\hline Sophistication & 1.37 & 1.78 & 0.00 & 9.00 & 66,336 \\
\hline Ln(Transactions) & 3.85 & 0.94 & 2.40 & 6.77 & 66,336 \\
\hline Transactions & 76.75 & 98.35 & 11.00 & 872.00 & 66,336 \\
\hline Ln(Assets held) & 3.95 & 1.49 & -6.91 & 9.97 & 66,336 \\
\hline Assets held & 0.13 & 0.29 & -0.06 & 21.28 & 66,336 \\
\hline Gender & 0.90 & 0.30 & 0.00 & 1.00 & 66,336 \\
\hline Ln(Age) & 4.07 & 0.26 & 2.77 & 4.50 & 66,336 \\
\hline Age & 60.50 & 13.58 & 16.00 & 90.00 & 66,336 \\
\hline Ln(Income) & 9.41 & 3.56 & 0.00 & 13.46 & 43,724 \\
\hline Income & 49.61 & 46.89 & 0.00 & 700.00 & 43,724 \\
\hline
\end{tabular}

Notes: This Table presents summary statistics according split according to whether investors invest $100 \%$ in socially responsible stocks (SRI) or invest less than $100 \%$ in socially responsible stocks (Conventional). PGR is the Proportion of Gains Realized, PLR is the Proportion of Losses Realized and DE is the Disposition Effect, calculated based on the number of realized gains (RG), realized losses (RL), paper gains (PG), and paper losses $(\mathrm{PL}) . \mathrm{I}(\mathrm{DE}>0)$ is an indicator variable equal to one when the disposition effect $(D E=P G R-P L R)$ is positive; zero otherwise. Sophistication is the investor's sophistication score. The variable Transactions is the total number of transactions over 2015. Assets held is the value of assets held in millions of Euros, Gender is a indicator variable equal to one if an investor is male; zero otherwise, Age is the age of the investor in years, Income is the self-reported gross yearly investor income in thousands of Euros.

the difference in disposition effect between socially responsible and conventional investors diminishes. Moreover, the percentage of the portfolio invested in socially responsible stocks has no significant effect on investors' disposition effect. We only find evidence for a differential disposition effect when investors invest at least $85 \%$ of their portfolio in socially responsible stocks. This suggests that our results are more likely to be driven by investors regarding themselves to be socially responsible investors than by characteristics of socially responsible stocks.

This paper contributes to the disposition effect literature and the socially responsible investment literature. The disposition effect literature shows that the disposition effect varies across investors based on their social interactions (Heimer, 2016; Rau, 2015) and investor psychology (Kadous et al., 2014; Chang et al., 2016). Our results suggest that the disposition effect also varies across investors based on their social preferences for certain investments. The socially responsible investment literature shows social preferences influence investment decisions (Webley et al., 
Table A.2

Summary statistics propensity score matching.

\begin{tabular}{|c|c|c|c|c|c|}
\hline & Mean & SD & Min & Max & $N$ \\
\hline \multicolumn{6}{|l|}{ SRI } \\
\hline$\overline{\mathrm{DE}}=\mathrm{PGR}-\mathrm{PLR}$ & 0.19 & 0.56 & -1.00 & 1.00 & 8,317 \\
\hline Sophistication & 0.87 & 1.39 & 0.00 & 9.00 & 8,317 \\
\hline Ln(Transactions) & 3.47 & 0.80 & 2.40 & 6.02 & 8,317 \\
\hline Transactions & 46.94 & 55.39 & 11.00 & 413.00 & 8,317 \\
\hline Ln(Assets held) & 3.33 & 1.48 & -6.91 & 7.42 & 8,317 \\
\hline Assets held & 0.07 & 0.15 & -0.01 & 1.67 & 8,317 \\
\hline Gender & 0.88 & 0.33 & 0.00 & 1.00 & 8,317 \\
\hline Ln(Age) & 4.05 & 0.28 & 2.77 & 4.50 & 8,317 \\
\hline Age & 59.13 & 13.95 & 16.00 & 90.00 & 8,317 \\
\hline Ln(Income) & 8.93 & 3.98 & 0.00 & 13.12 & 5,206 \\
\hline Income & 45.73 & 55.31 & 0.00 & 500.00 & 5,206 \\
\hline \multicolumn{6}{|l|}{ Conventional } \\
\hline $\mathrm{DE}=\mathrm{PGR}-\mathrm{PLR}$ & 0.13 & 0.41 & -1.00 & 1.00 & 12,386 \\
\hline Sophistication & 0.83 & 1.36 & 0.00 & 8.00 & 12,386 \\
\hline Ln(Transactions) & 3.43 & 0.74 & 2.40 & 5.36 & 12,386 \\
\hline Transactions & 41.88 & 39.13 & 11.00 & 213.00 & 12,386 \\
\hline Ln(Assets held) & 3.49 & 1.44 & -6.91 & 7.49 & 12,386 \\
\hline Assets held & 0.07 & 0.12 & 0.00 & 1.80 & 12,386 \\
\hline Gender & 0.86 & 0.34 & 0.00 & 1.00 & 12,386 \\
\hline Ln(Age) & 4.05 & 0.27 & 2.77 & 4.48 & 12,386 \\
\hline Age & 59.19 & 13.77 & 16.00 & 88.00 & 12,386 \\
\hline Ln(Income) & 9.07 & 3.93 & 0.00 & 12.77 & 7,537 \\
\hline Income & 47.18 & 40.28 & 0.00 & 350.00 & 7,537 \\
\hline \multicolumn{6}{|l|}{ Total } \\
\hline $\mathrm{DE}=\mathrm{PGR}-\mathrm{PLR}$ & 0.15 & 0.48 & -1.00 & 1.00 & 20,703 \\
\hline Sophistication & 0.85 & 1.37 & 0.00 & 9.00 & 20,703 \\
\hline Ln(Transactions) & 3.44 & 0.76 & 2.40 & 6.02 & 20,703 \\
\hline Transactions & 43.91 & 46.42 & 11.00 & 413.00 & 20,703 \\
\hline Ln(Assets held) & 3.43 & 1.46 & -6.91 & 7.49 & 20,703 \\
\hline Assets held & 0.07 & 0.13 & -0.01 & 1.80 & 20,703 \\
\hline Gender & 0.87 & 0.34 & 0.00 & 1.00 & 20,703 \\
\hline Ln(Age) & 4.05 & 0.27 & 2.77 & 4.50 & 20,703 \\
\hline Age & 59.17 & 13.84 & 16.00 & 90.00 & 20,703 \\
\hline Ln(Income) & 9.01 & 3.95 & 0.00 & 13.12 & 12,743 \\
\hline Income & 46.59 & 47.01 & 0.00 & 500.00 & 12,743 \\
\hline
\end{tabular}

Notes: This table presents summary statistics for the propensity score matching exercise in Table 6 split according to whether investors invest $100 \%$ in socially responsible stocks (SRI) or invest less than 100\% in socially responsible stocks (Conventional) and the two combined (Total). PGR is the Proportion of Gains Realized, PLR is the Proportion of Losses Realized and DE is the Disposition Effect. Sophistication is the investor's sophistication score. The variable Transactions is the total number of transactions over 2015. Assets held is the value of assets held in millions of Euros, Gender is a indicator variable equal to one if an investor is male; zero otherwise, Age is the age of the investor in years, Income is the self-reported gross yearly investor income in thousands of Euros.

2001; Bauer and Smeets, 2015; Riedl and Smeets, forthcoming). Our results suggest that in addition to investment decisions, preferences for socially responsible investments also affect trading behavior.

It would be interesting to directly relate social preferences for investments, which we expect to be driving our results, to the disposition effect. One approach would be to measure social preferences through online experiments (Riedl and Smeets, forthcoming), and combine this with brokerage data to measure the disposition effect. In addition, measuring social preferences and the disposition effect in a more controlled experimental environment could provide valuable insights, because it would allow to better control for alternative explanations. In this paper, we are able to control only for a limited set of investor characteristics. Instead of social preferences, there might be unobservable investor characteristics affecting both the disposition effect and investors' allocation towards socially responsible stocks. We leave it to future research to identify whether social preferences for investments or other (behavioral) investor characteristics are driving the effects identified in this paper.

\section{Appendix. Tables}

See Tables A.1 and A.2.

\section{References}

Barber, B.M., Lee, Y.-T., Liu, Y.-J., Odean, T., 2007. Is the aggregate investor reluctant to realise losses? Evidence from Taiwan. Eur. Financ. Manage. 13 (3), 423-447.

Barber, B.M., Odean, T., 2000. Trading is hazardous to your wealth: The common stock investment performance of individual investors. J. Finance 55 (2), 773806.

Barberis, N., Xiong, W., 2009. What drives the disposition effect? An analysis of a long-standing preference-based explanation. J. Finance 64 (2), 751-784.

Bauer, R., Koedijk, K., Otten, R., 2005. International evidence on ethical mutual fund performance and investment style. J. Bank. Finance 29 (7), 1751-1767.

Bauer, R., Smeets, P., 2015. Social identification and investment decisions. J. Econ. Behav. Organ. 117, 121-134.

Benson, K.L., Humphrey, J.E., 2008. Socially responsible investment funds: Investor reaction to current and past returns. J. Bank. Finance 32 (9), 1850-1859.

Bollen, N.P., 2007. Mutual fund attributes and investor behavior. J. Financ. Quant. Anal. 42 (03), 683-708.

Brown, P., Chappel, N., da Silva Rosa, R., Walter, T., 2006. The reach of the disposition effect: Large sample evidence across investor classes. Int. Rev. Finance 6 (1-2), 43-78.

Caliendo, M., Kopeinig, S., 2008. Some practical guidance for the implementation of propensity score matching. J. Econ. Surv. 22 (1), 31-72.

Chang, T.Y., Solomon, D.H., Westerfield, M.M., 2016. Looking for someone to blame: Delegation, cognitive dissonance, and the disposition effect. J. Finance 71 (1), 267-302.

Cuong, N.V., 2013. Which covariates should be controlled in propensity score matching? Evidence from a simulation study. Stat. Neerl. 67 (2), 169-180.

Dam, L., Scholtens, B., 2015. Toward a theory of responsible investing: On the economic foundations of corporate social responsibility. Resour. Energy Econ. $41,103-121$.

Derwall, J., Guenster, N., Bauer, R., Koedijk, K., 2005. The eco-efficiency premium puzzle. Financ. Anal. J. 51-63.

Dhar, R., Zhu, N., 2006. Up close and personal: Investor sophistication and the disposition effect. Manage. Sci. 52 (5), 726-740.

Edmans, A., 2011. Does the stock market fully value intangibles? Employee satisfaction and equity prices. J. Financ. Econ. 101 (3), 621-640.

El Ghoul, S., Karoui, A., 2017. Does corporate social responsibility affect mutual fund performance and flows? J. Bank. Finance 77, 53-63.

EUROSIF, 2016. European SRI study 2016.

Fabozzi, F.J., Ma, K., Oliphant, B.J., 2008. Sin stock returns. J. Portf. Manage. 35 (1), 82-94.

Fama, E.F., French, K.R., 2007. Disagreement, tastes, and asset prices. J. Financ. Econ. 83 (3), 667-689.

Feng, L., Seasholes, M.S., 2005. Do investor sophistication and trading experience eliminate behavioral biases in financial markets? Rev. Finance 9 (3), 305-351.

Ferris, S.P., Haugen, R.A., Makhija, A.K., 1988. Predicting contemporary volume with historic volume at differential price levels: Evidence supporting the disposition effect. J. Finance 43 (3), 677-697.

Frino, A., Lepone, G., Wright, D., 2015. Investor characteristics and the disposition effect. Pac.-Basin Finance J. 31, 1-12.

Galema, R., Plantinga, A., Scholtens, B., 2008. The stocks at stake: Return and risk in socially responsible investment. J. Bank. Finance 32 (12), 2646-2654.

Heath, C., Huddart, S., Lang, M., 1999. Psychological factors and stock option exercise. Q. J. Econ. 601-627.

Heimer, R.Z., 2016. Peer pressure: Social interaction and the disposition effect. Rev. Financ. Stud. 29 (11), 3177-3209.

Heinkel, R., Kraus, A., Zechner, J., 2001. The effect of green investment on corporate behavior. J. Financ. Quant. Anal. 36 (04), 431-449.

Hong, H., Kacperczyk, M., 2009. The price of sin: The effects of social norms on markets. J. Financ. Econ. 93 (1), 15-36.

Kadous, K., Tayler, W.B., Thayer, J.M., Young, D., 2014. Individual characteristics and the disposition effect: The opposing effects of confidence and self-regard. J. Behav. Finance 15 (3), 235-250.

Kahneman, D., Tversky, A., 1979. Prospect theory: An analysis of decision under risk. Econometrica 263-291.

Kaustia, M., 2011. Disposition effect. In: Behavioral Finance. John Wiley \& Sons, Inc., pp. 169-189.

Kempf, A., Osthoff, P., 2007. The effect of socially responsible investing on portfolio performance. Eur. Financ. Manag. 13 (5), 908-922.

List, J.A., 2003. Does market experience eliminate market anomalies? Q. J. Econ. 118 (1), 41-71. 
List, J.A., 2004. Neoclassical theory versus prospect theory: Evidence from the marketplace. Econometrica 72 (2), 615-625.

Mackey, A., Mackey, T.B., Barney, J.B., 2007. Corporate social responsibility and firm performance: Investor preferences and corporate strategies. Acad. Manag. Rev. 32 (3), 817-835.

Novemsky, N., Kahneman, D., 2005. The boundaries of loss aversion. J. Mark. Res. 42 (2), 119-128

Odean, T., 1998. Are investors reluctant to realize their losses? J. Finance 53 (5), 1775-1798.

Rau, H.A., 2015. The disposition effect in team investment decisions: Experimental evidence. J. Bank. Finance 61, 272-282.

Renneboog, L., Ter Horst, J., Zhang, C., 2008. Socially responsible investments: Institutional aspects, performance, and investor behavior. J. Bank. Finance 32 (9), 1723-1742.

Riedl, A., Smeets, P., 2017. Why do investors hold socially responsible mutual funds? J. Finance (forthcoming)
Scholtens, B., 2005. What drives socially responsible investment? The case of the Netherlands. Sustain. Deve. 13 (2), 129-137.

Shefrin, H., Statman, M., 1985. The disposition to sell winners too early and ride losers too long: Theory and evidence. J. Finance 777-790.

SIF, 2016. Report on US sustainable, responsible and impact investing trends 2016. Sustainalytics, 2017. Sustainalytics Global Compact Compliance Service (Retrieved 26 July 2017). http://www.sustainalytics.com/global-compact-compliance-ser vice/.

UN Global Compact, 2016. The Ten Principles of the UN Global Compact.

Weber, M., Camerer, C.F., 1998. The disposition effect in securities trading: An experimental analysis. J. Econ. Behav. Organ. 33 (2), 167-184.

Webley, P., Lewis, A., Mackenzie, C., 2001. Commitment among ethical investors: An experimental approach. J. Econ. Psycol. 22 (1), 27-42.

Williams, G., 2007. Some determinants of the socially responsible investment decision: A cross-country study. J. Behav. Finance 8 (1), 43-57. 